\title{
The influence of idealism on curbing schoolers' defiant behaviours
}

\author{
Shinga Alphonsus Joseph \\ School of Education, Federal College of Education (Technical), Gombe, Gombe State, Nigeria
}

\begin{abstract}
This study intends to examine defiant behaviours among schoolers at the three levels of education in Gombe metropolis, which has reached a critical point. To guide the study, the research takes a descriptive survey design. Three research questions focusing on the defiant behaviours among schoolers were formulated. Eight institutions were randomly selected and a total number of 146 respondents were also randomly sampled for the study. A structured questionnaire with 12-items was designed. Results revealed that these defiant behaviours has caused high rate of dropouts among schoolers and so affected their contribution in the task of the nation building. It is the position of the paper that idealism, which emphasizes self-awareness and self-knowledge, can be used to tackle the problem of defiant behaviours among schoolers.
\end{abstract}

Keywords: defiant; schoolers; curbing; idealism; behavior; discipline

\section{INTRODUCTION}

A simple look across humanity in general, one will notice that there has always been for man a means by which he transmits his values, norms and skills. This is with the sole aim of ensuring that there is the continuous transmission of knowledge and ideas from a generation to the next.

It is in this light that Jabaar (2008) maintains that man has always been in need of education not only as a necessary part of growing up, but as a requirement for taking positive and active part in the activities of his societies. It is in the same spirit that Ndagana (2012) posited that education is a very crucial industry for the production of skills, positive attitudes, knowledge and personality growth upon which national existence so much depends. It is then not surprising that nation of the world devout time and resources towards the development of the educational sector. This is with the sole aim of producing disciplined, educated and enlightened personalities.

However, what we see today are all sorts of defiant behaviours that betray the reason for the existence of such a sector. Defiant behaviour is the direct opposite of the intended result of establishing educational institutions. The concept of defiant behaviours refers to those unruly behaviours that constitute hazards to the progress of educational system. It is the general indiscipline exhibited by schoolers at different levels of education.

This can be seen in acting contrary to the rules and regulations, norms and values of a particular society, community or school system. Going by this, Sanda (2007) credits Socrates' opinion of defiant and indiscipline behaviours as those unruly behaviours. Socrates 
further asserts that young people of today love luxury; they have bad manners, they scoff at authority and lack respect for their elders. He concluded that they contradict their parents and tyrannized their teachers.

These behaviours are capable of disrupting and dwelling the educational standard. For Taiwo (2004) as quoted by Issa (2008) opined that what we are witnessing today in the education sector is a sad reflection of corruption in the society and the low priority placed on standardization. The schoolers who are supposed to be the direct beneficiaries of this venture have indulged themselves in all sorts of miscreant behaviours that put the sector into jeopardy. This betrays the effort of those involve in the business of educating.

However, the principle of idealism which is predicated on man's freedom can offer a solution. This principle exposes the schoolers to freedom and all the elements of their environment as well as allowing them to be more responsible towards their choices. Since freedom leads to a strong sense of duty, and duty leads to determination, it therefore follows that a reasonable help can be found. To what extend does defiant behaviours sabotage the educational industry? What are the causes of these defiant acts? How can the principle of idealism be used to reduce those defiant behaviours to the barest minimum? These and other questions will this paper try to address.

The word "idealism" arose from the word 'idea'. Idealism, for Omoregbe (1991) is a system of thought or doctrine which emphasizes the role of the mind, spirit or soul as the ultimate constitutive element of reality. In other words, idealism denies the reality of matter and maintains that in the last analysis only the mind, spirit or soul is real. This opinion has largely influenced the views on education. According to Nzulumike (2010) that man has a soul and this soul is superior to the body. So the aim of education as far as the idealists are concerned is to strength the link between man's soul and his ultimate reality, by developing him (man) spiritually.

This school of idealism is championed by Plato as the father of philosophical thought, with other distinguished idealist like St. Augustine of Hippo, who modified the work of Plato and maintained that the world of God is the ideal world. Another renowned scholar of the idealist is Rene Descartes with his popular dictum-"cogitto ergo sum" I think therefore I exist. A notable figure in idealism is Immanuel Kant, who together with Hegel put forward the idea that the human world was made up of mind-made objects in that it consisted of a series of structures, Sharma and Hyland (1991).

The principle or the philosophy of idealism, that emphasizes the spiritual aspect of man, has in the opinion of Amaele (2007) the following aims on education: To develop in the individual a critical mind to appreciate things around him through inquiries, to teach the individual morals and aesthetic values, to generate self-awareness, self consciousness in the individual so as to take his or her rightful place in the society and to teach the supremacy and existence of God and his norms as to the individual members of the society. These aims and objectives are to lead the learner to be more aware of his or her self in terms of discovering oneself or being conscious of one's being.

The aims also dwell more on the moral growth, and place those class subjects or disciplines that are the heart of the realization of these purposes on a higher pedestal.

\section{Statement of the Problem}

Even though the educational sector of any country of the world goes without its challenges, the Nigerian system of education is sometimes rated quite low when compared to most countries of the world. It is not surprising then when one puts into cognizance the continuous decline in good values and morals within the system. The system in Nigeria has 
been bedeviled by ills that derail its dignity and standard. This is made evident in the attitudes or behaviours of some of the students. These defiant acts have undermined the value and progress of the sector towards a more globally accepted standard of education. It has betrayed the nation's internal stability towards development.

Students who schooled within the Nigeria systems of education are not only looked down upon with distain, but are subjected to all kinds of tests to really authenticate their certificates. The dynamics of these activities need to be addressed. For there has to be that enabling environment without which meaningful progress in learning is not possible. In view of the ever prevailing incidences of display of defiant behaviours by schoolers, this study is poised at looking for measures to curb the sad situation.

\section{Purpose of the Study}

This research intends to:

i. Find out whether defiant behaviours exist among schoolers.

ii. Identify the most frequently occurring defiant behaviours.

iii. Ascertain the causes of these defiant behaviours among schoolers.

iv. Suggest modalities, using the principle of idealism, on how to proffer solutions.

\section{Research Questions}

i. What forms of defiant behaviours exist within schoolers?

ii. What are the frequently occurring defiant behaviours?

iii. What are the causes of these defiant behaviours?

\section{Significance of the Study}

This research will benefit the schoolers and their teachers at all levels of education, the parents of the schoolers who are co-teachers and government who are the policy makers. To the schoolers, they will discover and become more aware of the ills of these defiant acts. For the parents, they will come to know and appreciate more of their children and know best on how to assist them in terms of the dangers that lies with those ills.

To the government, it will serve as a spring board on which to be more alert towards these ills in the educational sector. Through this, the government will also succeed in making the schoolers to grow and become people with integrity, to be proud of not only by their parents or teachers but by the society at large.

\section{METHODOLOGY}

\section{Design of the study}

The design of the study was descriptive survey. It seeks to find out the solution to defiant behaviours among our schoolers. Because this is the situation, according to Awotunde and Ugodulunwa (2004), of making a descriptive assertions about some population after distribution of certain traits or attributes. 


\section{Area of study}

The survey was carried out in Gombe metropolis. The areas include- Jekadafari, Tudun wada, Sabon layi, BCGA, Federal low cost, and Tudun hatsi. Gombe metropolis serves as both a local government area and Gombe state capital.

\section{Population of the study}

Those who constitute the population of the study are the pupils, students and teachers of the following schools-Jekadafari primary school (JKF), Success Bliss model academy (SBMA), Government science secondary (GSSS), St James secondary school (SJSS), Government day secondary school (GDSS), Modibo Tukur college of Arabic and Islamic studies ( MOTCAIS), Federal college of education (Tech) (FCE (T.)) Finally, Gombe state university (GSU).

\section{Sample and sampling technique}

The population for the study comprises 40 pupils and 8 teachers in the 2 primary schools, 40 students and 8 teachers in the 4 secondary schools and 40 students and 10 teachers in the 2 tertiary institutions, bringing to the total number of 146 respondants. Simple random sampling technique was used. Each unit of the population was given a serial number and written on a piece of paper, folded and dropped in a container. The folded papers properly mixed and each piece was picked and recorded as a sample selected.

\section{Instrument for data collection}

The instrument for data collection is a structured questionnaire developed by the researcher. Each of the items had a four-point rating scale of strongly agree SA (4), agree A (3), disagree D (2) and strongly disagree SD (1)

\section{Method of data collection}

A total of 146 copies of the questionnaire were administered to the respondants and total copies 124 copies were duly recovered after four days. The researcher with the help of a research assistant administered the questionnaire by going there themselves.

\section{Method of data analysis}

The data collected were analyzed using frequency counts and mean statistics. 2.60 and above as strongly agreed, 2.50 as agreed, 2.40 as disagree and 2.30 below as strongly disagreed.

Research question 1: What forms of defiant behaviours exist among schoolers?

Table 1 shows the existence of defiant behaviours among schoolers in our educational institutions. The finding in Table 1 shows that defiant behaviours exist in our educational institutions in Gombe, and this is not particular to the schools in the study area alone. Ogbonna (1999) confirms this and shows that such defiant attitudes exist among the primary schoolers elsewhere. For him, these are the most common anti-social behaviours found among them. This occurs due to the prevailing moral problems in the society, because according to Jaabar (2008) education and educational institutions are passive reflection of 
social order, in other words, schoolers exhibit behaviours that are the exact reflection of the larger society.

Table 1. Shows the mean response on the existence of defiant behaviours among schoolers.

\begin{tabular}{|c|c|c|c|c|c|c|c|c|c|c|c|}
\hline \multirow{2}{*}{ S/N } & Offence & EMP & T & L & ID & SM & C & DR & LT & HG & S \\
\cline { 2 - 9 } & Schools & & & & & & & & & & \\
\hline 1 & JKF & 2.00 & 2.80 & 2.60 & 2.00 & 2.00 & 2.00 & 2.40 & 2.60 & 2.00 & 2.00 \\
\hline 2 & SBM & 2.00 & 2.60 & 2.50 & 2.40 & 2.00 & 2.00 & 2.45 & 2.60 & 2.00 & 2.00 \\
\hline 3 & GSSS & 2.50 & 2.80 & 2.60 & 2.50 & 2.40 & 2.00 & 2.60 & 2.70 & 2.40 & 2.40 \\
\hline 4 & SJSS & 2.40 & 2.40 & 2.60 & 2.40 & 2.00 & 2.00 & 2.40 & 2.40 & 2.40 & 2.40 \\
\hline 5 & GDSS & 2.60 & 2.70 & 2.70 & 2.60 & 2.40 & 2.30 & 2.60 & 2.70 & 2.40 & 2.50 \\
\hline 6 & MOTCAIS & 2.40 & 2.40 & 2.60 & 2.00 & 2.00 & 2.00 & 2.40 & 2.40 & 2.30 & 2.40 \\
\hline 7 & FCE (T) & 2.60 & 2.60 & 2.40 & 2.40 & 2.50 & 2.40 & 2.40 & 2.50 & 2.40 & 2.40 \\
\hline 8 & GSU & 2.60 & 2.40 & 2.40 & 2.40 & 2.50 & 2.40 & 240 & 2.50 & 2.40 & 2.40 \\
\hline
\end{tabular}

Key: Examination malpractice -EXP, truancy - T, lying - L, improper dressing - ID, sexual misconduct - SM, cultism - C while disrespect for authorities - DR, lateness - LT, hooliganism - HG and stealing - S.

Research question 2: what are the frequently occurring defiant behaviours?

Table 2. Shows the mean responses of the frequently occurring defiant behaviours.

\begin{tabular}{|c|c|c|c|}
\hline S/NO. & Items & Mean & Interpretation \\
\hline 1 & Examination malpractice & 2.50 & Agreed \\
\hline 2 & Truancy & 2.70 & Strongly agreed \\
\hline 3 & Lying & 2.70 & Strongly agreed \\
\hline 4 & Improper dressing & 2.70 & Strongly agreed \\
\hline 5 & Sexual misconduct & 2.40 & Disagreed \\
\hline 6 & Cultism & 2.40 & Disagreed \\
\hline 7 & General disrespect & 2.50 & Strongly agreed \\
\hline 8 & Lateness & 2.70 & Strongly agreed \\
\hline 9 & Hooliganism & 2.40 & Disagreed \\
\hline 10 & Stealing & 2.40 & Disagreed \\
\hline
\end{tabular}


Table 2. Based on the findings in Table 2, it was gathered that among the aforementioned defiant behaviours that exist among schoolers, some occur very frequently (strongly agreed), some frequently (agreed) and a few occur occasionally (disagreed). For instance, in terms of mode of dressing, the findings shows that improper dressing occur very frequently, and this confirms what Usani (2012) opined that immoral dressing among schoolers especially the female students in tertiary institutions is on the high sight.

Research question 3: What are the causes of defiant behaviours?

Table 3. Shows the mean responses of causes of defiant behaviours among schoolers.

\begin{tabular}{|c|c|c|c|}
\hline S/NO & Item & Mean & Interpretation \\
\hline 1 & Inadequate teacher-student ration & 2.70 & SA \\
\hline 2 & Qualification of the teacher & 2.30 & D \\
\hline 3 & Unhealthy parent-teacher relationship & 2.60 & SA \\
\hline 4 & Implementation of stringent measures & 2.60 & SA \\
\hline 5 & Inadequate provision of facilities & 2.60 & SA \\
\hline 6 & Negative peer-group influence & 2.70 & SA \\
\hline 7 & Consumption of drugs and alcohol & 2.70 & SA \\
\hline
\end{tabular}

Table 3. Evidence from the data in Table 3 shows the various factors that are responsible for the occurrence of these defiant behaviors among schoolers. Both categories of the respondents almost unanimously agreed that these factors are the major causes of these defiant activities. One of these factors is the negative peer group influence among the schoolers.

This factor was earlier pinpointed and linked by Ogbanna (1999) as an environmental factor that causes such activities. The environmental factor can be a reason when a particular peer group of schoolers come across other schoolers whose background do not respect or value honesty and high moral standard, then the bad once are likely to influence the others negatively.

\section{DISCUSSION OF FINDINGS}

One of the aims and objectives of idealism is the emphasis on education for selfawareness. This great need for self-awareness is obtained through self-examination. Just as Socrates, the father of idealism maintains that 'an unexamined life is not worth living'. This will lead the schoolers to think on such concepts as wisdom, justice, courage, loyalty as a means of self discovery.

Once there is the self-awareness one is likely to discover the truth from within. Truth from within entails those moral values that are innate in man, enshrined and endowed by the creator. This will not only answer the question regarding the existence of the forms of defiant behaviours in the schoolers, rather, it will to a large extent avert it. Because moral 
values are supposed to serve as compass towards good and upright life style, especially when they are properly inculcated in the schoolers.

This fact is further buttressed by Akpomi (2002) when she said that both teachers and the schoolers must be disciplined and dedicated in other to limit the existence of these defiant behaviours. When these are found they are not likely to be found wanting in all the listed defiant behaviours because their hearts will yearn towards something beyond the material world and so try to shun those negative activities.

It is needless to say that education entails all these processes of meaningful existence with established values system. This to a large extend, if being discovered by our schoolers, can help to curb those defiant behaviors. For example, the "I" and "thou" relationship, where the learner as the "I" and the teacher as the "thou" emerge from the principle of justice and good moral values. For Mogbo and Mallum (2002) this means a genuine and emphatic relationship that will enable the schoolers to trust their teachers, especially counselor so as to ventilate all tension.

This is the situation where the student or the learner is not seen as an object that can be manipulated for selfish ends or being talked over, but teaching and learning process is seen from a mutual and reciprocal perspective. This leads to a change in the negative behaviour of the schoolers, because man's life is only meaningful in a relationship, and relationship entails proper activities of people. It is more among schoolers who will reject those defiant behaviours and to replace them with more accepted social values. This will lead to the extent that no one will ask about the frequency of defiant behaviour, but how frequent can the schoolers be assisted within the cordial relationship.

Another important aim and objective of idealism in education is to develop in the individual a critical mind to appreciate things around through critical inquiries. This appreciation could come through respect for constitutional authority, respect for democracy and freedom, respect for dignity of labour and respect for social justice. By employing logical, critical and rigorous thinking in diffusing knowledge from the pool of opinions, it will provide in the schoolers a potent tool to confront reality. Such reality will help in reducing the causes of defiant behaviour in the schoolers.

Because they will discover that such reality is the appreciation of the dignity of labour and hard work which will curb and reduce the burden of and the causes of cheating and stealing within examination or elsewhere. This is further buttressed by the fact that the Nigerian child has more crisis-laden life to battle with. However, this will re-create in the schoolers the sense of being creative, to have initiative and the generation of new ideas. When these noble virtues are re-emphasized and re-inculcated on the schoolers at all levels of education, it is likely that they will depart from these defiant acts.

\section{CONCLUSION}

Idealism embraces all issues related to human life and development in all facets of existence. It does more within the educational system where it reflects on how best to transmit lasting values which defiant behaviours among schoolers militate against. That is why there is the dare need to use idealism as a pragmatic tool in curbing the prevailing defiant behaviours in them. Our educational sector gets all it takes to make our standard compete favorably with the rest of the developed nations of the world. Therefore if we must change the international community's view on Nigeria's educational parameter in the face of global challenges, then idealism is not only relevant, but a pragmatic tool. 


\section{Recommendations}

In other to curb defiant behavior among schoolers, these strategies are put forward:

1. One of the causes of schoolers' defiant behaviours as discovered in the work is the instability of the teachers. It is from a stable teacher that comes a stable environment which gives birth to a stable student. The teacher should be reasonably remunerated to achieve this stable mind, so as to produce stable schoolers who will reject defiant behaviours.

2. Another factor to curb defiant behaviour is the re-discovery of moral values and principles. This will help in identifying those defiant behaviours thereby helping the schoolers to build their personality towards the right direction that will subsequently reject defiant behaviours.

3. Creating an enabling environment for mutual relationship will to a large extend inspire the schoolers in the direction towards their world view. This world view will help the schoolers in terms of transfer of learning from a class room situation to a concrete life situation.

4. There is the need to properly confront issues and situation appropriately through the use of guidance and counseling services. Through this service, school system can assist and re direct the erring schoolers. This will to a large extend assist the school in properly directing the schoolers on issues bordering them and proffering solutions.

5. There is the need to improve parent- teacher relationship. This will help in the cooperation between the two parties so as to be of great help to the schoolers especially the defiant.

\section{References}

[1] Akpomi M. E. (2002). Maintenance of discipline in schools: Suggestions for year 2000 and beyond. Journal of Educational Studies, 8(1); 129-13.

[2] Amaele S. (2007). Understanding the philosophy of education. Ibadan. Bounty Press Ltd.

[3] Anakwe A. I. (2008). Dimension and resultant effects of examination malpractice in our post primary schools. Jos Journal of Education, 1(1); 29-34.

[4] Awotunde P. O., Ugodunlunwa C. A. (2004). Research method in education. Jos. Fab Anieh Nigerian Ltd.

[5] Issa O. A. (2008). The impact of cultism and examination malpractices on the quality of education in the $21^{\text {st }}$ century Nigeria. A paper delivered at centre for continuing education, Federal polytechnic, Offa, Kwara State.

[6] Jabaar S. O. (2008). Discipline in education: implication for political leadership. A paper presented at the $26^{\text {th }}$ annual conference of philosophy of education association of Nigeria (PEAN), Ago-Iwoye, $7^{\text {th }}-10^{\text {th }}$ October.

[7] Mogbo I. N., Mallum Y. A. (2002). Crisis intervention for effective teaching and learning in Nigerian secondary schools. Journal of Educational Studies, 8(1); 83-86.

[8] Ndagana J. M. (2012). Education and national security. A lead paper presented at the $2^{\text {nd }}$ national conference of the school of education, FCE (T.) Gombe, 8-12 October.

[9] Ogbonna B. B. O. (1999). Stealing and Lying among Primary School Children: Causes and Remedies. Pankshin Journal of Arts and Social Science Education, 2; 10-16. 
[10] Omoregbe J. (1991). A simplified history of western philosophy. (Vol. 3) Ikeja: Joja educational research publishers Ltd

[11] Sanda Y. Y. (2007). Impact of indiscipline on the future of Nigeria education: issues for consideration. Journal of Educational Studies, 13(1); 66-72.

[12] Sharma A. P., Hyland J. T. (1991). Philosophy of education for Nigeria. Ibadan: Gbabeks publishers Ltd.

[13] Usani M. O. (2012). Immoral dressing among girls in tertiary institutions: Effects and preventive measure. Gombe Education Studies, 2(1); 137-140.

[14] Abdulrahaman W. Lawal, International Letters of Social and Humanistic Sciences 3 (2014) 53-59.

[15] Alaba E. Dare, International Letters of Social and Humanistic Sciences 3 (2014) 73-79.

[16] Grema Maina Bukar, Yohanna A. Timothy, International Letters of Social and Humanistic Sciences 4 (2014) 9-21.

[17] M. N. Modebelu, F. K. Igwebuike, International Letters of Social and Humanistic Sciences 4 (2014) 40-48.

[18] Akor Isaiah Akem, Victor Tavershima Ukeli, International Letters of Social and Humanistic Sciences 4 (2014) 49-59.

[19] Sule Maina, International Letters of Social and Humanistic Sciences 4 (2014) 87-96.

[20] Nwachukwu Uche Emma, International Letters of Social and Humanistic Sciences 5 (2014) 1-12.

[21] Peace Ebele Ilechukwu Chukwbikem, International Letters of Social and Humanistic Sciences 8(1) (2014) 1-17.

[22] Odo John Ogar, International Letters of Social and Humanistic Sciences 8(1) (2014) 28-33.

[23] Halima Sidi Bamall, International Letters of Social and Humanistic Sciences 8(1) (2014) 50-55.

[24] Elizabeth Morenikeji Titilayo Adediran, Albert Oluyomi Kehinde, International Letters of Social and Humanistic Sciences 8(1) (2014) 66-75.

[25] S. A. Kazeem, K. Y. Balogun, International Letters of Social and Humanistic Sciences 8(2) (2014) 108-119.

[26] Nneka Rita Udoye, Victor Etim Ndum, International Letters of Social and Humanistic Sciences 8(2) (2014) 130-139.

[27] Sanusi L. Sa'adatu, International Letters of Social and Humanistic Sciences 8(2) (2014) $140-147$.

[28] Dennis Agama Eka, International Letters of Social and Humanistic Sciences 8(2) (2014) 170-182.

[29] Nayereh Shahmohammadi, International Letters of Social and Humanistic Sciences 8(2) (2014) 183-191. 
[30] Godwin E. Itua, International Letters of Social and Humanistic Sciences 8(3) (2014) 200-207.

[31] Rowland U. Aleshi, Clementina N. Iloh, International Letters of Social and Humanistic Sciences 8(3) (2014) 208-216.

[32] Hannatu Abdullahi, International Letters of Social and Humanistic Sciences 8(3) (2014) 217-223.

[33] Fowoyo Joseph Taiwo, International Letters of Social and Humanistic Sciences 8(3) (2014) 244-251. 